\title{
Assessing challenges to ineffective communication in government institutions: A case study of Vuwani area, Limpopo, South Africa
}

\begin{tabular}{|c|c|}
\hline \multicolumn{2}{|c|}{$\begin{array}{l}\text { Authors: } \\
\text { Bernard N. Rasila }{ }^{1} \\
\text { Mavhungu E. Musitha }\end{array}$} \\
\hline \multicolumn{2}{|c|}{$\begin{array}{l}\text { Affiliations: } \\
\text { IIntegrated Monitoring and } \\
\text { Evaluation, Limpopo } \\
\text { Department of Education, } \\
\text { South Africa }\end{array}$} \\
\hline \multicolumn{2}{|c|}{$\begin{array}{l}\text { 2Information Services, } \\
\text { Limpopo Tourism Agency, } \\
\text { South Africa }\end{array}$} \\
\hline \multicolumn{2}{|c|}{$\begin{array}{l}\text { Corresponding author: } \\
\text { Bernard Rasila, } \\
\text { rasilabn@edu.limpopo.gov.za }\end{array}$} \\
\hline \multicolumn{2}{|c|}{$\begin{array}{l}\text { Received: } 08 \text { June } 2017 \\
\text { Accepted: } 05 \text { Sept. } 2017 \\
\text { Published: } 08 \text { Dec. } 2017\end{array}$} \\
\hline \multicolumn{2}{|c|}{$\begin{array}{l}\text { How to cite this article: } \\
\text { Rasila, B.N. \& Musitha, M.E., } \\
\text { 2017, 'Assessing challenges } \\
\text { to ineffective communication } \\
\text { in government institutions: } \\
\text { A case study of Vuwani area, } \\
\text { Limpopo, South Africa', } \\
\text { Africa's Public Service } \\
\text { Delivery and Performance } \\
\text { Review 5(1), a177. https:// } \\
\text { doi.org/10.4102/apsdpr. } \\
\text { v5i1.177 }\end{array}$} \\
\hline \multicolumn{2}{|c|}{$\begin{array}{l}\text { Copyright: } \\
\text { ( 2017. The Authors. } \\
\text { Licensee: AOSIS. This work } \\
\text { is licensed under the } \\
\text { Creative Commons } \\
\text { Attribution License. }\end{array}$} \\
\hline \multicolumn{2}{|l|}{ Read online: } \\
\hline 回部品: & $\begin{array}{l}\text { Scan this QR } \\
\text { code with your } \\
\text { smart phone or } \\
\text { mobile device } \\
\text { to read online. }\end{array}$ \\
\hline
\end{tabular}

Twenty-five schools were burnt. Others were damaged. This is during the protest at Vuwani area. Five houses were also torched. Businesses were brought to complete shutdown for more than three months.

The protests followed lack of effective communication and consultation between Municipal Demarcation Board (MDB), government and communities on matters of municipality boundaries. The MDB took a decision that parts of Vuwani would be incorporated into the Malamulele villages to establish a new municipality, LIM 345. This angered Vuwani communities allegedly because they were not consulted. The MDB denied the allegations.

A qualitative study was conducted in the area where there were interactions with government, and community members. Media reports were also used to substantiate the findings. It was revealed through the study results that although there was some communication between government institutions including the MDB and community members, this was not effective, hence violent protests. This paper is intended to provide strategies for future effective communication by state functionaries to avoid violent protests caused by ineffective communication.

\section{Introduction}

Vote for what? ... These were the words of some residents of Vuwani as they boycotted local government elections that took place on 01-03 August 2016. Instead of queuing to vote, community members of this area gathered on 03 August 2016 and played soccer involving teams of elders and for those in preschool (Daily Sun, 04 August 2016:1).

Three days before the elections, the government and traditional leaders of villages such as Masia, Vyeboom, Mashau and other affected areas of Vuwani signed a Peace Agreement to guarantee peaceful election in the area. The agreement also included a clause to allow learners to go back to schools (Capricorn Voice 03-09 August 2016:2).

This agreement followed three months of total shutdown by angry residents who embarked on protests and forced business, transport, schooling and other economic activities to standstill. Of course, this was in a response to earlier violent protests by the Malamulele residents who demanded to be removed from the Venda-speaking-dominated Thulamela Municipality and have their own Xitsonga-speaking municipality. The president of the ruling party and the country succumbed to pressure and violence, which also shut down all economic activities and schools for weeks. On the other hand, the country, through one of its constitutional institutions, the Municipal Demarcation Board (MDB), was embarking on assessing viability of a number of small municipalities across the country. The MDB found that some municipalities in Vhembe district and other areas had to be merged as they were not economically viable. These are the municipalities that, for example, do not have opportunities to generate their own income and hence are failing to deliver. The municipality for the people of Malamulela was also found not viable, hence incorporating villages of Vuwani.

The MDB claimed to have consulted community representatives in Vuwani area. It was also claimed that community leaders and traditional leadership agreed for the area to be incorporated in to the new municipality so that it would become viable. This meant that they would belong to a new municipality outside of Makhado Municipality. However, other members were against this move. They even took the MDB to Limpopo High Court in Polokwane on 29 April 2016 to have the decision to incorporate them into Malamulele set aside (News 24 report of 12 May 2016). After 
the court dismissed their application, meetings were held with leaders of community structures including the King of the Vhavenda nation Khosikhulu Toni Mphephu Ramabulana to find out a solution to the problem to no avail. Community members led by a group called Pro-Makhado claimed that there was no effective communication between them and the state.

The main message of government led by the minister of Cooperative Governance and Traditional Affairs (COGTA) and other ministers, mayors, and members of the Executive Council was aimed at requesting community members to allow schooling to continue. This failed despite many meetings held between May and July 2016. SABC News reported that the shutdown in the area started again on 05 September 2017.

\section{Brief background}

After the burning of schools in 2016, the Department of Education delivered 74 mobile classrooms at a cost of more than R44 million. The classrooms stood empty for a period of three months with no route to deliver furniture and other materials as there were no accessible routes. Both learners and teachers could not go to schools in fear of their lives and avoiding reprisals from protesters. It wasn't until 04 August 2016 that learners were allowed to go to school, but still only a few attended. This is after the Department of Education had withdrawn the 1897 Grade 12 learners who were taken to the three camps of Tivumbeni, Makhado and Mastec outside Vuwani.

At face value one entering Vuwani area may believe that there are elements of racial tensions between vaTsongaand Vhavenda-speaking people. When asked, many of the Vhavenda-speaking people who are dominating the area replied, 'We never requested for the municipality and why should we be led by vaTsonga?' (A rongo vhuya ra humbela masipala. Khee vha tshi toda $u$ ri ita vhalanda vha vaTsonga?) However, it is surprising as they have inter-marriages in these villages. At least 9 out of 10 homestead speak the two languages fluently.

It is unfortunate that the tension by people of Vuwani refusing to be incorporated in to the newly established municipality is strengthening day by day. This in turn is also creating hatred between vaTsonga who are currently in the LIM 345 municipality. Most of them argue that the Vuwani people are racists and undermine vaTsonga-speaking people. They argue that they do not need them to be part of 'their' municipality.

President of South Africa, Mr Jacob Zuma, met the king of Vhavenda, Khosi Toni Mphephu Ramabulana, and the leaders of the community of Vuwani in February 2017 with the aim of addressing the problem. However, the president could not address community members. Some of the reasons provided by the office of the presidency is that the president was advised not to address only the Vuwani part of the LIM
345 but include those residing in Malamulele area who embraced and are running the LIM 345 municipality currently (eNCA, 07 May 2017). On the same day, the minister of COGTA, Mr Des van Rooyen, was booed (eNCA, 06 February 2017). The president announced that Vhembe district of which LIM 345 is a part should provide services to people of Vuwani as they do not want to be part of LIM 345 and as they cannot be returned back to Makhado local municipality. Many meetings were held after this announcement, but it proved to be difficult and even illegal for the district municipality to perform the tasks that are to be performed by a local municipality.

The people of Vuwani had another one-day shutdown where they gave government until the end of August 2017 to make sure they get services from Vhembe district. Despite many meetings, this did not materialise. The community members embarked in one more shutdown protest on 07 September 2017. This is another indication that the meetings are not working and suggests that there has to be a different way of communication between the government and leaders in the Vuwani area. Hence, this paper is aimed at providing a better communication strategy.

\section{Methodology}

As indicated supra, this study was conducted using a qualitative methodology. Data were gathered from the community members, media coverage and through observation. A number of communities' meetings were attended to observe deliberations by stakeholders on demarcation issues.

\section{Research question}

Research questions were used to guide interaction with members of the community in Vuwani area. However, it needs to be noted that other data were gathered from observation and media coverage:

- What were the causes of shutdown protests in Vuwani?

- What were the methodologies used by the MDB to engage communities on municipal boundaries?

- What were the reasons for the rejection of re-demarcation of Vuwani to Malamulele?

\section{Hypothesis}

- There was no proper consultation between the MDB and the Vuwani communities.

- The introduction processes of the new Malamulele Municipality to Vuwani area bring tribalism challenges.

- There is nothing wrong with the new municipality but some community leaders are afraid of losing control and benefits by being incorporated into a new municipality.

- Government relied too much on leaders within the community and made inroads to community members communication gap. 


\section{Literature review Effective communication}

There are different definitions of 'communication'. Basically, it is understood as passing of messages from the sender through a medium to the recipient. Effective communication, on the other hand, as defined by Rasila and Mudau (2014), is imperative for development in areas such as Vuwani.

Effective communication is also described as the communication characterised by community participation wherein community members are empowered with information and are part of the identification of their needs, challenges, intervention plans, implementation thereof, evaluation and monitoring in an environment conducive for them to take issues of their own development into their own hands by becoming active participants and owners of the whole process (Chambers 2010).

In the case of Vuwani, community members would be expected to be part of the whole demarcation process of their area into a new municipality. According to the Constitution of the Republic of South Africa (1996), communities should be involved in the matters that affect them, and failure to consult the Vuwani residents was tantamount to violation of the Constitution. According to Musitha (2016b:66), any process that is imposed on the people without their participation is illegitimate because the majority did not take part.

Sun Tzu (2005:4) also indicates that if people are treated with benevolence, faithfulness and justice, then they will be of one mind and be glad to serve joyfully in difficulty and forget their challenges. This is easy if people trust their leaders, something that lacked in Vuwani situation. Sun Tzu (2005) continues to indicate that people respect leaders whom they think treat them well. He writes:

the one who treats me well is my leader, the one who treats me cruelly is my enemy, the question is, which side has a humane government and which one has cruel government. (p. 4)

Many people of Vuwani remain stranded and argue they were not consulted properly. Figure 1 provides a communication model of effective communication for rural areas such as the Vuwani area.

The following is an explanation on the model (Figure 1): Municipal Demarcation Board (MDB) is a sender of the message (1). MDB begins by sharing the message to recipients, in this case the community members of Vuwani (2). The two parties have common understanding on the importance of changing boundaries (3). They both develop mutual understanding and jointly create a common message towards realisation of discussed objectives of new boundaries (4). The two parties take initiatives jointly to the realisation of the objectives of the message (5). At the end, the two parties accept accountability on the end results. If the end result is good, they rejoice and celebrate together. If the results are not favourable, the two parties go back to the drawing board without pointing fingers. Therefore, MDB and community members will never fight again as they plan, implement and monitor projects together. Community members can be involved through their local structures, which the Demarcation Board claimed they did.

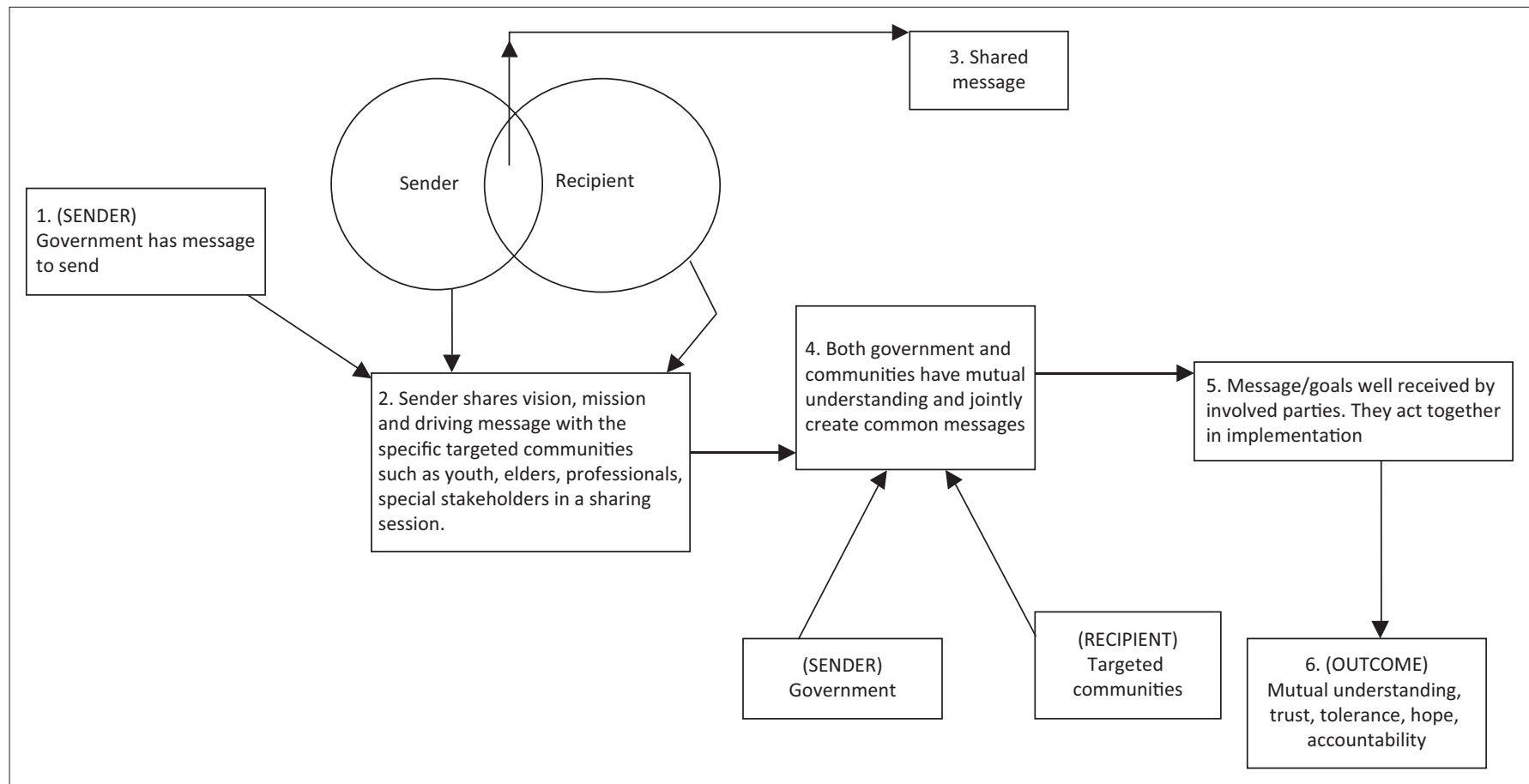

Source: Rasila and Mudau 2013

FIGURE 1: A model of effective communication for rural development. 


\section{Government efforts on provisioning effective communication}

Government spends money in communication activities. They use different media such as posters, radio and television. Others also have own departmental newsletters. Following former president Thabo Mbeki's State of the Nation Address in 2003, government also established community development workers (CDWs). Vuwani area also has these 'cadres' of development.

There are other structures such as the ward committees and traditional leaders. However, as Disoloane and Lekonyane (2011) put it, because of lack of clarification of roles and clear reporting lines these structures fail to fulfil their duties. It was also not possible for government to use other communication channels such as media when the situation is not conducive. However, there were a number of media statements from the group called Pro-Makhado which demanded Vuwani area remain in Makhado and not the new municipality, the LIM 345. Government through the provincial office also released a number of communiqués through the media. The two groups on many occasions were seen as blaming one another for breaking the agreement and acting opposite or contrary to the discussions.

After many meetings the Pro-Makhado group seemed to agree that they cannot change the boundaries now and should wait until 2019 as per the law. Going out of the communities they argue through their spokesperson $\mathrm{Mr}$ Msobo Sambo:

All we want is to be re-incorporated to Makhado municipality nothing else. We never asked for a municipality. We are comfortable here as Makhado. Those who requested the new municipality should enjoy it and leave us alone.

Unfortunately, government relied more on these community leaders and they became the first and preferred communication hubs.

\section{Local government and municipal boundaries}

The Republic of South Africa consists of three spheres as stated in the Constitution: national, provincial and the local sphere or local government. The local sphere of government consists of municipalities (Constitution, Chapter 7). The executive and legislative authority of a municipality is vested in its municipal council. A municipality has the right to govern, on its own initiative, the local government affairs of its community subject to national and provincial legislation as provided by the Constitution. On the other hand, the national and provincial governments may not compromise or impede a municipality's ability or right to exercise its powers or perform its function.

According to Section 152(1) of the Constitution, the objectives of local government include provision of democratic and accountable government, to ensure provision of services, to promote social and economic development and to encourage the involvement of communities in matters of local government which include re-establishment of their boundaries. The municipality must also strive within its financial and administrative capacity to achieve the objectives set out.

Section 153 demands that the municipality must structure and manage its administration and budgeting and planning processes to give priority to basic needs of the community. Chapter 7 of the Constitution (1996) implies that a municipality must be viable to be able to provide and cater for its communities. The Demarcation Board therefore assists in assessing viability of existing municipalities and determines new boundaries mainly to make sure it will be able to prioritise service delivery for the people.

One way to involve the community members on matters of local government is through the Integrated Development Plan (IDP) processes. Musitha (2016a) argued that this is the process that contributes to the realisation of the goals of the redistribution policy in South Africa where those who were underprivileged by the apartheid regime are empowered.

According to the Demarcation Board, there was a need for municipalities in Vhembe district to be assessed as directed by the national sphere with the main aim of creating viable municipalities that will be able to respond to the needs of the communities, hence the establishment of the new entity, LIM 345 Local Municipality which the community of Vuwani is against.

Following the recommendations of the MDB, Mutale Municipality has been de-established and its area of jurisdiction was split between Thulamela and Musina. The MDB is one of the independent and democratic guardian institutions referred to as Chapter 9 institutions by the Constitution of the Republic of South Africa (The Constitution of SA, Act 108 of 1996). The MDB has powers to re-demarcate boundaries of all municipalities in the country following a process which includes consultation. Municipal boundaries are re-established ensuring that municipalities remain economically viable, among others. But the president is construed to have imposed undue influence on the MDB when he suggested at the funeral service of one of the beloved ministers (Collins Chabane) from Malamulele that the area would get a municipality and indeed they got it. This municipality has applied to the Limpopo Geographical Names Committee to name it after Collins Chabane.

The community of Vuwani responded with violent protests that saw schools in Vuwani area getting burnt by the community members. Community members could not vote in numbers on 01-03 August 2016. As reported by the news 24 across May and June months, over 52000 learners were affected with 1895 doing Grade 12, the grade to allow them to the higher learning.

Vhafamadi Secondary School (Figure 2) was left with no classroom following the burning of all the classrooms. 
Figure 3 indicates the fire gutted Mavhina Primary School. At the back are mobile classrooms provided by the Limpopo Department of Education. Learners of Lupedze Primary School (Figure 4) were also left with no option than gathering in one room for both teaching and feeding.

\section{The 2016 local government elections in Vuwani}

According to the Independent Electoral Commission (IEC) of South Africa, the African National Congress (ANC) won the

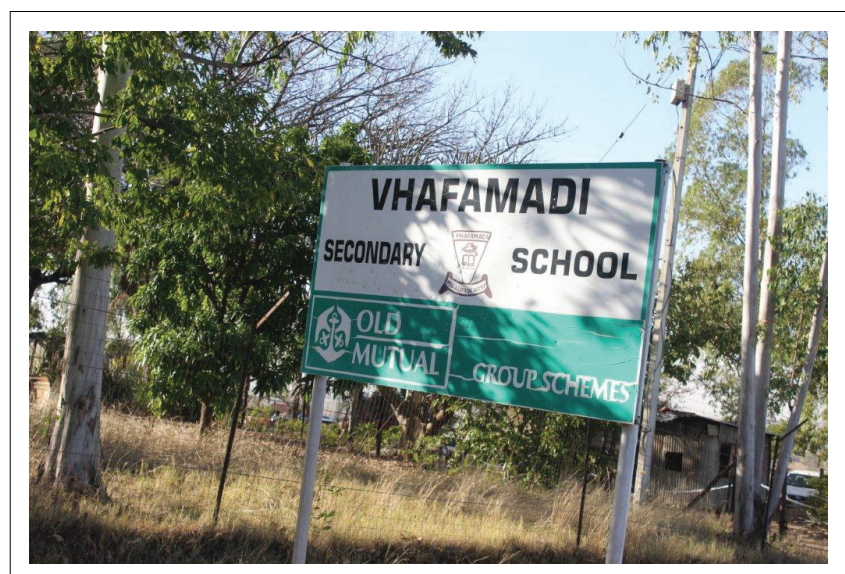

Source: Mr Harley Ngobeni, Limpopo Department of Education.

FIGURE 2: All 21 classrooms of the Vhafamadi Secondary School were torched. The department provided temporary classrooms.

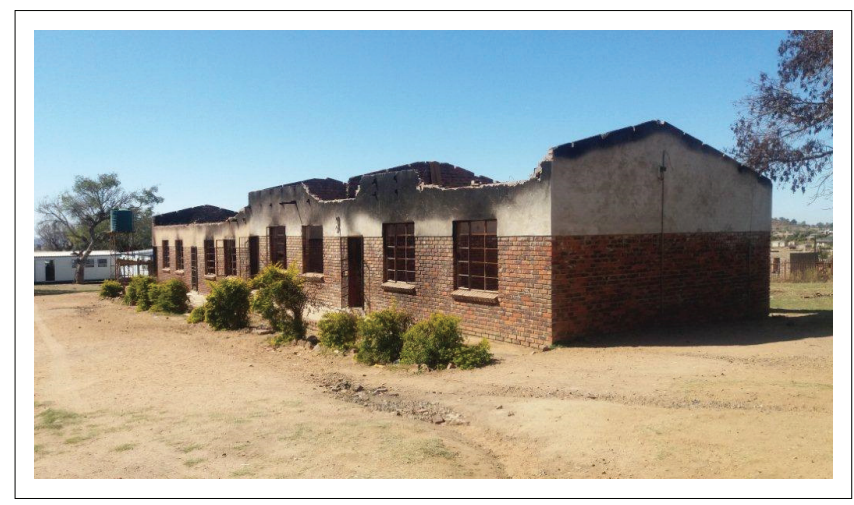

FIGURE 3: Mavhina Primary School in Vuwani after burning. At the back are mobile temporary classrooms provided by the government.

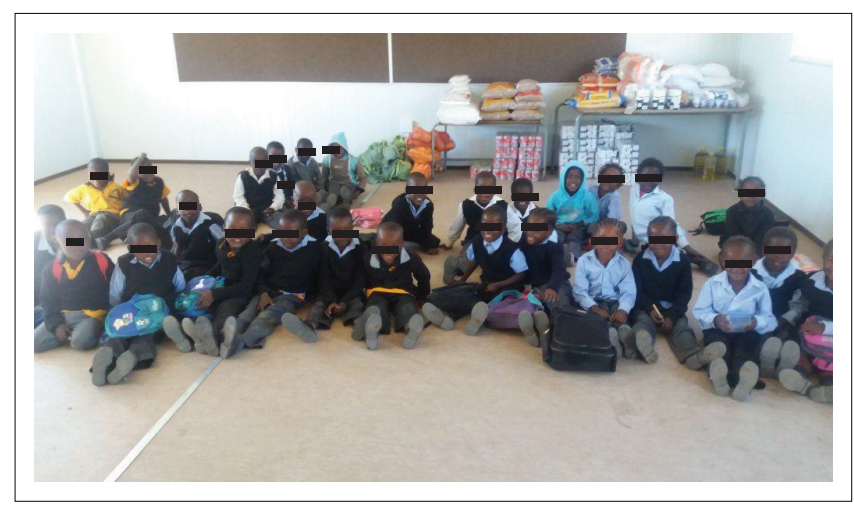

FIGURE 4: School burning in Vuwani left learners of Lupedze seating on the floor in the temporary classroom which also serves as a storeroom for their food. disputed new municipality, the LIM 345, that incorporates Vuwani and Malamulele in Limpopo, with overwhelming $84.65 \%$ of the vote (IEC results announcement, 05 August 2016). The new municipality has 71 seats and 35 wards.

The IEC said the fewest number of votes cast in Vuwani's 13 wards was at Masakona Primary School with only five and most at Kurhuleni Primary School with 155. In total, the IEC indicated that 5000 voters cast their votes out of the total 40000 registered voters. This means that 35000 voters did not vote. Generally, of the 2.5 million registered voters in Limpopo Province, 1.662 million cast their votes. This indicates that many voters did not participate in the democratic process of voting in the province. The study by Musitha (2016:67) had found that the general low turnout for consultation might suggest that the residents do not understand the importance of the action that is planned. The IEC also indicated that the trend has cut across the country.

\section{Ethical considerations}

There are no financials to disclose and participants are declared not to have interest. Participants are also protected from being disclosed.

\section{Findings}

\section{The demarcation and other government structures missed the target}

Traditional leaders in South Africa receive their services and salaries from the Department of COGTA. It is therefore easy for government to engage traditional leaders as representatives of community members in their territories. This study revealed that there is a general belief among government and business sectors that the best access to rural communities is through traditional affairs.

While this may be correct, it is not an effective structure for communicating with communities for every governance issue at the local level. Some community members hold different views from that of traditional leaders depending on the matter under scrutiny. Some community members believe traditional leaders can easily collude with government because they benefit from government in one way or the other. This is consistent with the findings of Musitha (2012) in that traditional leaders are suspected of being remnants of colonial and apartheid systems. The benefits include that they earn salaries from government, hence the resistance by some members to abide by agreements between government and traditional leaders in terms of the community being incorporated in to the newly established municipality.

Government and the MDB could not realise this and wasted time by engaging with them, while communities were disassociating with them. With the model of effective communication, government considered engaging communities directly. There are also indications that at times, being afraid 
of losing control of their subjects, traditional leaders were not negotiating with government in good faith; hence, there were different messages reaching community members and frustration on part of the government.

At a meeting held by the Inter-Ministerial Committee (IMC) at the king's palace, there was an agreement that the protest in Vuwani will be lifted to the excitement of one citizen who then made a call for stability. In the same evening, he was called to one senior traditional leader's palace and told to withdraw the call while IMC believed they reached agreement amicably.

Pro-Makhado seemed also not to fully cooperate with all traditional leaders in the area. They have alliance with one or few who are instrumental in a campaign against inclusion of the area in to the newly established municipality, the LIM345. Some traditional leaders had some reservations on the protest. Reliance on traditional leaders proved to bring in a communication gap and hence ineffective communication between government as a whole and the MDB in particular with the community members. Some traditional leaders were left out of the discussions.

\section{The misinformation of Vuwani communities}

People of Malamulele area made a call in the past 10 years or more calling government to allow them to have their own municipality. These are neighbours to Vuwani communities. Government, through the MDB, indicated that the requested municipality would not be viable. Unfortunately, leaders who visited the area sent conflicting messages. When they protested and burnt schools, the Premier of Limpopo visited the area and indicated that he understood their demand. So did the president of the country Mr Jacob Zuma during the funeral of a struggle hero and then minister in his cabinet, Mr Collins Chabane. Here there were also indications that the municipality may even be named after the late minister.

Perception then was created that indeed there would be a new municipality for people in Malamulele. Unfortunately, during the protest, some community members echoed statements indicating the main reason they wanted to be removed from Thulamela Municipality was that they did not get proper treatment as they are Xitsonga-speaking while the Thulamela is dominated by Vhavenda-speaking. In contrast to the claims, the study by Musitha (2016:57) revealed that tribalism and service delivery were not the reason for the demand but lack of governance as the majority of Malamulele did not attend dysfunctional ward committee meetings where they would know about the service delivery projects in the area. This was because of the vastness of the wards in the area.

When a decision was taken that the community of Vuwani would be included in the newly established municipality incorporating those in Malamulele, Vhavenda started also to utter statements such as 'We cannot be led by VaTsonga' (Ri nga si vhuswe nga vhatsonga), with others even calling them Matshangana. At that stage, there was no municipality established called Malamulele, but Vuwani community members became angry and some corners perpetually fed them with the information that they were going to be 'swallowed' by VaTsonga. Surprisingly the two groups live together characterised by inter-marriages. 'Ri dzula rothe nga mulalo fhedzi hu si musi ri tshi lwela maanda a u vhusa' [We live together in peace but not when we have to fight for power, (author's own translation)], said one interviewed elder in Vuwani. This suggests that they live together in harmony as long as possible if they are not competing for resources. Interviewed in Vuwani streets, one learner who preferred anonymity said 'Nne thi todi u vhuswa nga mutsonga' [I do not want to be led by Tsonga-speaking person (author's own translation)].

The study has revealed that although there are supporters revolting against the new municipality in Vuwani, misinformation played a major role in creating the situation in the area.

\section{The disbandment of the Pro-Makhado group}

Immediately when the violent protest erupted in May 2016, the Pro-Makhado disbanded itself and left a leadership vacuum. Following that move, schools were set alight one after the other while South African Police Services (SAPS), as per their statements, were monitoring the situation. Their presence could not save schools from burning.

Government through the IMC visited a number of affected areas trying to plead for peace. In most of these meetings, there were local traditional leaders but these meetings proved to be fruitless. Traditional leaders would echo sentiment of government but did not have power and control over the people. The shutdown continued. Both government and traditional leaders did not have a plan to restore peace. Some interviewed community members indicated that some traditional leaders were supporting the protest as they were afraid of a revolt from their subjects.

To add to the frustration to government, the protest was leaderless. This means that the communication gap existed between government and the community members as the vehicle called Pro-Makhado group was no more. This increased frustration on the part of the community.

There were however some so-called community leaders who were arrested and brought to book. When the peace agreement was signed, no one had been sentenced yet. The Pro-Makhado group was then revived and being vocal on media complaining that they were not part of the peace agreement which indicated that learners were allowed to schools from 04 August 2016 and that the shutdown was lifted. The study here revealed that there is no complete trust between government and the main community structure, Pro-Makhado, and therefore communicating to Vuwani through them may not be fully effective. 
Inter-ministerial committee addressing community for media coverage - Message was also irrelevant

In Vyeboom, part of Vuwani area, some community members complained that they were not contacted. They argued that they saw ministers coming with media and they were not for the community members. Community members argued that their main worry was not on resuming of learning and teaching but that they were left being part of Makhado Municipality and not part of the newly established municipality that incorporates Malamulele. They blamed COGTA minister who went to the area and visited a school and started teaching a class and was shown on national television. These people indicated that they had a view that they should allow learners to schools but were irritated when the minister taught and did not address their issue of concern.

The study here revealed that even when government tried to play the Public Relation Exercise, it instead of attracting learners to school irritated the community. This is part of less effective communication between government and the communities of Vuwani. One middle aged man argued, 'Minister vha khou takalela u bva kha TV vha sa ri fhi phindulo yo teaho. Ri do vha sumbedza' (Ministers wanted to be on TV while they are not addressing our issues. This government cares less about us. We will show them who we are). It is clear that the IMC meetings were not effective to the extent that communication would be effective in calming the situation. All the community members wanted was to be left at Makhado local municipality and the IMC was calling for peace.

\section{Government frustration - Defiance also coming from religious groups}

When government continued to be frustrated with the Vuwani issue, they resorted to involving the Vhembe Pastors' Forum, a Christian religious group. Led by the chairperson, the forum addressed community members at the sport centre. 'Let's open the book of Luke chapter 11 from verse 11', said Dean Alunamutwe Rannditsheni. The verse reads as follows:

What father among you, if his son asks for a fish, will instead of a fish give a serpent, or if he asks for an egg, will give him a scorpion? (Holy Bible English Standard 200, Luke Chapter 11, Verse 11).

The religious leader fuelled the anger of the community members who then branded the government as the father who did not listen to the needs of its children. Then the protest continued. Again the government had failed in bringing effective communication as they identified the wrong third party endorsement (religious groups) that sent message different from peace-making in the name of the Holy Father. Those interviewed applauded the forum for this.

Trying to manage the damage caused by the protest, government took Grade 12 learners to three centres. This was just an attempt to save future of these learners who were to proceed with their studies at the institutions of higher learning. However, there was a concern about Grades 1-11 who were just at home and not attending any schooling. Some hope came with the signing of the peace agreement on 28 August 2016, which allowed schooling to resume in the area but for a certain period and with some conditions.

\section{Control and benefits in Makhado Municipality}

Some of the community members interviewed indicated that they did not have a problem in falling in to any municipality. They indicated that it would not even affect their daily living as they would not even relocate. They however showed concern that some so-called community leaders were adamant to stay in Makhado because they had control. Included in the list were political leaders in Makhado and Vhembe Municipalities and traditional leaders. There were those who were suspected of benefiting from the tenders and also the influence plus those who had future desires for political positions. It was said also that should the area be incorporated in to those from Malamulele there was a risk that political leaders and those in influence in Makhado might find it difficult to settle in the new municipality which they believe the Malamulele leaders had already planned and were coming with more villages and wards than the ones in Vuwani, hence more control in the municipality council and tender processes. However, the council was established in mid-August 2016 at the Malamulele Boxing Club Hall as they did not have offices. Vuwani community members were promised that there would be additional interactions between government and community members on municipal boundaries. On that day the municipality without name had already been formed, which was a surprise if indeed there would be additional negotiations. Even leaders of ProMakhado were subtle about the main aim of the protest, but some community members attested to the fact that the struggle was for access to economic power. 'Rine ri vhuelwa nga mini arali masipala wav ha na dzina lifhio. Tenda makhadzi wanga na vhazwala hu si na a no do pfuluwa' (What do I gain from the name of a municipality? As long as we do not find our aunts and cousins relocating), said one old man interviewed in Ha-Mashau.

\section{Subtle tribalism matters}

Most parts of Vuwani area comprise people who speak both Tshivenda and XiTsonga. They have even entered into intermarriages. This situation had potential of distracting the attention of the researchers. On face value, no one can think there are elements of tribalism between the XiTsonga people and Tshivenda as they live together.

However, it needs to be noted that when the Pro-Malamulele, XiTsonga speakers demanded to be allocated a separate Malamulele Municipality, some indicated that they are putting such demand to be separated from the Vhavendadominated Thulamela Municipality. What is realised or heard on streets of Vuwani is that 'Rine a ri todi u vhuswa nga 
vhatsonga' (We do not want to fall under XiTsonga people). On the other hand, those in Malamulele keep saying that they have fought for their municipality to move out of the Vhavenda-speaker-dominated municipality. Government failed to identify and deliberate on this factor. One man said, 'There cannot be any tribal issues if there is nothing to fight for. Now that there are tenders and power to fight for you see tribalism'.

\section{Discussions}

It is evident from the findings that we can put a number of arguments illustrating that government has failed and is still failing to resolve challenges in Vuwani area.

Firstly, different stakeholders involved in communication in the area fail to reach consensus. The Pro-Makhado team and government failed on several occasions to reach consensus through communication.

Secondly, many ordinary community members in Vuwani seem to believe that falling into the newly established LIM 345 local municipality is equal to be under the control of vaTsonga-speaking people. To fight against dominance by the group, they attend and comply with any structure that seems to protect their integrity. They also forget all other important activities such as the education of their own children fighting as if falling in to a municipality will see them relocating their houses.

Thirdly, there are elements of focus on economic benefit for those leading the protest. Some are believed to be afraid of losing dominance when they move from Makhado where their respect and economic influence is entrenched to join those who seem to be already entrenched in LIM 345. However, this is never told to general protesters.

Moreover, the Pro-Makhado group, after realising that all the time they engage they end up not winning, then agreed on a position that they will get services from the District of Vhembe. They knew there are both technical and legal challenges with this decision. President Jacob Zuma announced on 06 February 2017 that Vhembe will service the people of Vuwani as both government and the MDB could not reverse the decision to include this area in to LIM 345. Unfortunately, legally the area belongs to LIM 345. There is the possibility again that assistance from the district will not serve anything and the fact that government therefore does not want LIM 345 to be economically viable but to cut away some of its people and their resources. Those in LIM 345 mainly from the Malamulele areas will view it as if government listen more to Vuwani area and this may increase hatred based on tribal issues. Some of the observations are discussed in the following sections.

\section{The death of the Municipality Demarcation Board starts in Vuwani}

It was only at the end of July 2016 that the government and traditional leaders from Vuwani signed an agreement that determined that learners would be allowed to go to schools. However, there were some concerns as the Pro-Makhado group insisted they were not part of the deal (SABC News, 28 July 2016). On the set date of 04 August learners did not pitch in greater numbers to schools. When interviewed, some said that traditional leaders did not make such a call after signing the agreement. Some further argued that the traditional leaders were afraid of their own subjects. However, there was no more violence in the area. This again was the result of lack of effective communication between traditional leadership and community members. Government also did not do enough to bring communities on board.

The agreement also meant that the matter concerning the Municipal Boundary in Vuwani would still be opened after elections due on 03 August 2016. Starting the engagement of communities in matters of the boundaries in this area was a confession by government that at first instance there was no proper consultation and communication. This mistake would be costly. Funds would be spent again on same processes. Some institutions such as the Demarcation Board would be undermined not only by people of Vuwani abut also by those in other areas. People would then determine boundaries for the Board or cause chaos as the government would succumb to the pressure. Government for the first time admitted openly that it had failed to reign over the Vuwani people.

There are other areas government would encounter challenges across the country. In Limpopo, people of Moutse area in Sekhukhune district want to fall under municipalities in Mpumalanga Province. Those in Bushbuckridge in Mpumalanga have interest in belonging to Limpopo Province. Other municipalities soon to experience challenges include Tlokwe and Ventersdorp plus a Matatiele one. Government has to keep hope that communities around the country do not emulate the Vuwani stance by finding ways to communicate effectively with the community members. Some people of Vuwani keep saying, 'Arali wha tshi thetshelesa whathu vha Matatiele rine a vha ri thetshelesi nga mini?' [If they can reach some agreements in Matatiele, why can't they reach such with us? (author's own translation)].

\section{Police visibility in the violent area loses value}

In a meeting held at the Vhembe District Municipality Chamber, police reported on the situation in Vuwani where they indicated there were 24 torched schools. When interviewed, some of the members of South African Police responded that their duty did not involve preventing mob from destroying properties. When asked what they do, one said, 'monitoring the situation'. They argued that there were some laws of the country that they might easily break if they tried to impose force on the protesters.

The community members were aware of this 'weakness' of the police. Those interviewed indicated that they were protected by Chapter 2 of the Constitution of the country which provides them with the right to association, protest and even the freedom of speech. The same people ignored 
the section of the same chapter which guides that they have to respect the rights of others and therefore could destroy schools and deny learners the right to education.

All these and other weaknesses made the communities less concerned about the visibility of the police officials. People were therefore no longer afraid of being arrested. They knew more about their right and little about their obligations, and it seemed the running of the legal system in the country provides room for this perception. The killing of 34 miners in Marikana on 16 August four years ago and the subjection of government, mine owners and police to commission that saw even the suspension of the Police Commissioner Ria Piyega got cited by some police officials who said, 'If you try to protect the property and the country you will be fired or arrested for that and your kids will suffer'. This implied that police officials watched when the schools were burnt in Vuwani area. In this case, as Rasila and Musitha (2016) argued, police in South Africa watch people in their destruction roles as they feared the protective rights the community members had. Community members also believed that the South African government acted and provided services only if community members embarked on violent protests. 'Havha vha so ngo toda u ri vhulaha sa vhathu vha Marikana. Ri do farisa muthu a fhelelwa nga mushumo' [These must not kill us like what they did in Marikana. They will end up losing their jobs (author's own translation)], said one learner during their march at the Vuwani fire station, one of their meeting areas, showing how powerless police are in the situation.

\section{Deafening silence of government on matters of concern}

After two full months of no schooling in the area of Vuwani, representatives of community structures including the traditional leadership, politicians and members of the pastors forum gathered at the Office of the Premier of Limpopo Province, the highest office in the province, where an agreement was reached to allow learners to go back to school, businesses to function again and people to be allowed to travel to and from nearby towns. This however came with a condition that there was a need for the relevant government departments to continue engaging with the communities looking at mainly the reversal of the decision by the Demarcation Board. The agreement was reached in August 2016 but there has never been any fruitful engagement; hence, the leader of Pro-Makhado, a group that is eager to see the government reversing the decision, commented on three radio stations, Phalaphala FM, Munghana Lo Nene FM and Thobela FM of the South African Broadcast Corporations (joint stations called SABC-Combo):

If this is not changed, there will be again a shutdown in January 2017 where learners will not go to school, businesses not functioning and there will be no travelling up and down.

Indeed, when schools reopened on 18 April 2017 for the second term, learners were forced not to go to school. Newly appointed Minister of Police, Mr Fikile Mambalula, visited the area and addressed community members on 20 April
2017. As reported in both SABC Radio and TV News, ANN7 $\mathrm{TV}$ and community radio stations on the same day, Mbalula called for peace in the area but that could not change the situation. The Inter-Ministerial Committee continues to engage the community structures but they all seem to address issues on the periphery and not touch on the main issue. Importantly, the community is demanding not to be included in the new LIM345 local municipality together with Malamulele area communities but government representatives visiting the area are focusing mainly on the following:

- peace to be restored

- learners be allowed to go to school

- opening of businesses in the area.

\section{Conclusion}

Informed by the findings above, it can be argued that the Government of South Africa and its democratic structure, MDB, failed to conduct effective communication with the people of Vuwani area. This poor communication led to extensive damage where 24 schools were torched and 5 were at tempted. Currently learners of the Vuwani area are using temporary structures. It will take a decade or two to get the schools running smoothly in the area. This is because the province needs an amount of billions of rands to refurbish current aged infrastructure and there are not enough funds in its coffers. The man-made damage in Vuwani increases this burden to resources of government.

There are three main components of the communication process. These are the sender of the message or communicator, the channel and the recipient. In this study, government targeted the traditional leaders as their channel who could not pass the intended message to the communities. At all times, the channel should be relevant for the smooth running of the communication process. The message on the other hand was not relevant.

Government embarked on the resuming of learning and teaching when the target audience need message on the boundary issue.

Instead of the MDB interacting with protesters, it was nowhere to be seen. To the community members, government gave them communicators who do not have their issues at heart and hence communication breakdown.

The model for effective communication meant for communication with rural communities is best suited to deal with poor communication between an institution and its target audience. The communication gap between the government and community can at any time cause unnecessary conflicts like the damages to schools in Vuwani area. On the other hand, it is worth mentioning that South Africa is gradually becoming ungovernable by being the victim of its own democracy and poor communication. People are more exposed to their rights and less to their obligations. 
It is also high time that the country look at reviewing some parts of its constitution which is now 22 years old. Current laws were made when the country was gaining democracy and many such are aligned to complete freedom of the then disadvantaged black people. Now that the black people are leading and in majority, there is a need to strengthen some rules to make sure perpetrators are not left to do as they wish under the protection of the Constitution of the country.

In summary, it can be argued that Government used the wrong channels to communicate to community members of Vuwani. Government also missed the target recipients for effective communication and relied more on traditional leadership which is also part of the protest community. The messages were also irrelevant as they focused on restoring stability while communities need a talk on municipality boundaries.

It seems there is still a long way to go to attain complete stability in the area irrespective of what becomes the final 'agreement'. If, for example, community succumbs to the pressure and they end up falling into the new municipality, they will forever complain of issues they do not approve. If the community members get what they need, it will set the wrong precedence and the function of the MDB is undermined.

Unintentionally and perhaps unaware, leaders of government continue to put more focus on the people of Vuwani in terms of engagements. They do so without considering that Vuwani area is part of LIM 345 municipality according to law and following the last decision taken by the MDB. This makes those in Malamulela see government as dividing the two areas and fuelling hatred. Mr. J. Nkuna, representative of the Pro-Malamulela who are championing the existence of the LIM345, said over the radio station, 'Government leaders must not address us separately. We belong to LIM 345 and are affected by the same issues'. Again this is an indication that the government is missing the target, and may lead to a continuous distrust between these two groups. Time and again the area may experience protests, which are violent in nature. The model for effective communication in rural development suggested in the 'Literature review' section can be useful for government in restoring sustainable peace in the area.

\section{Acknowledgements}

The authors would like to thank the Pro-Makhado team, ProLim345 team and community members for their participation in the interviews. Also to be acknowledged are all sources including media as indicated in the reference section.

\section{Competing interests}

The authors declare that they have no financial or personal relationships which may have inappropriately influenced them in writing this article.

\section{Authors' contributions}

Both authors contributed equally to the writing of the article. B.N.R. led the research while M.E.M. provided assistance in the process.

\section{References}

Capricorn Voice: Vuwani boycotts elections, 03 - 09 August 2016

Chambers, G., 2010, Seminar: Revolution in development, Wits University, viewed 6 February 2010, from http://www.khanya-aicdd.org

Daily Sun: Community of Vuwani boycott elections, 04 August 2016

Disoloane, V.P.P. \& Lekonyane, B.C., 2011, The role of community development workers within the South African Local Government, Department of Public Admin, UNISA, Pretoria, South Africa.

eNCA TV News: Vuwani on fire, 12 May 2016

eNCA TV News: Schooling to be disrupted again in Vuwani, 6 February 2017

News 24: Holand, T., 2017, 'Community members of Vuwani booed van Rooyen', 6 February 2017.

Holy Bible English Standard, 2001, Luke Chapter 11 verse 11.

IEC, Results Announcement, 05 August 2016, Pretoria, South Africa.

Mbeki, T., 2003, State of the nation address, Cape Town, Parliament of South Africa, 2003.

Musitha, M.E, 2012, 'The role of Traditional authorities in integrated development planning policy implementation with reference to Limpopo Province', unpublished PhD thesis, University of Pretoria.

Musitha, M.E., 2016a, 'Integrated development plan as a redistribution policy in South Africa: Prospects and challenges', European Journal of Research in Social Sciences 4(6), 20-30., Vol. 4 no 6, ISSN 2056-5429.

Musitha, M.E., 2016b, 'The challenges of name change in South Africa: The case of Makhado Town', Open Journal of Social Sciences 4, 57-68. https://doi.org/ 10.4236/jss.2016.42010

Musitha, M.E., 2016c, 'Governance theory paralysis: Case of Malamulele of the Thulamela Municipality in Limpopo Province', Journal of Public Administration and Policy Research. https://doi.org/10.5897/JPAPR2015.0340

SABC-Combo Radio Stations: Several news hours and current affairs bulletins (6h007h00 in all stations), 2016

Rasila, B.N., 2013, 'Citizen participation in local government: The importance of effective communication in rural development', International Journal of Communication Development 1(1), 12-18. https://doi.org/10.11634/233 028791301321

Rasila, BN \& Mudau, J., 2014 'An effective Communication Framework for rural development', Prime Journal of Social Sciences 3(3), 612-617.

Rasila, B.N., 2015, 'South African Government and its communities at war: The legacy of the struggle for democracy', Journal of Education, Psychology and Social Sciences 3(1), 65-71., ISSN 1339-1488.

Rasila, B.N. \& Musitha, M.E., 2016, 'The lack of effective communication influences xenophobic attacks in South Africa', British Journal of Education, Society \& Behavioural Science 13(3), 1-11.

Sun Tzu, 2005, The art of war, Shambala, Boston, MA.

The Constitutional Assembly, 1996, The Constitution of the Republic of South Africa, 1996, The Parliament of South Africa, Cape Town. 